\title{
QUIZIZZ WEBSITE AS AN ONLINE ASSESSMENT FOR ENGLISH TEACHING AND LEARNING: STUDENTS' PERSPECTIVES
}

\author{
Dinda Firly Amalia
}

English Education Student, Language and Science Faculty, University of Wijaya

Kusuma Surabaya, Indonesia

Corresponding Author Email: dindafirlyamalia@gmail.com

\section{A B S T R A C T S}

This paper aimed to investigate the students' perspectives toward the use of Quizizz as an online assessment tool for English teaching and learning, especially on a formative one. The research design of this study was descriptive qualitative. The subjects of the study were 20 students of Dynamic English Course. The data was collected by asking the students to fill the questionnaire. The data analysis was implementing the Likert Scale. The result of the study showed positive perspectives of the students toward the use of Quizizz. In conclusion, the students strongly agreed that Quizizz has an attractive display which is interesting and fun, students can't cheat during the test, Quizizz creates a competitive atmosphere in the classroom, and Quizizz is better than the offline traditional test.

\author{
A R T I C L E I N F O \\ Article History: \\ Received: May, 2020
}

Revised: June, 2020

Published: June, 2020

\section{Keywords:}

Quizizz,

Assessment,

English Teaching and

Learning,

How to cite: Amalia, D. (2020). Quizizz Website as an Online Assessment for English Teaching and Learning: Students' Perspectives. Jo-ELT (Journal of English Language Teaching) Fakultas Pendidikan Bahasa \& Seni Prodi Pendidikan Bahasa Inggris IKIP, 7(1), 1-8. doi:https://doi.org/10.33394/joelt.v7i1.2638

\section{INTRODUCTION}

Nowadays, technology has experienced rapid development. Fouts (2000) states that the world where we live has already been a technical world. Most of the society aspects get influenced by the development of technology. It is obvious that all society's segments have changed by the development of technology dramatically. It will be continued in the future which can not be ignored. Fouts (2002) also states that schools have to be a part of the changes. Research is supposed to proceed with the assumption that technology is and going to continue to be a growing element within the schools. As technology develops rapidly, there will create new technologies, new resources, and new strategies of learning. New trends are supposed to be followed by teachers. Internet, mobile application, and technology platform need to be used in the classroom activities. There are many ways to stimulate students and teachers to find alternative motivations for teaching and learning using technology. Many applications and technology platforms that teachers can use in the process of teaching and learning English. They can be used not only as media for teaching but also for assessing the students.

Barbosa (2005) states that in the process of teaching and learning English, assessment is one of the important keys to the learning experience which influences the way students approach their learning. Assessment revises how and what students wish to study, as well as how much time they devote to different tasks and learning resources. It cannot be denied that students' interaction with the assessment process has an impact on their future learning experience and the development of their learning approach. Bury (2017) states that 
assessment plays a key role in improving and strengthening learner motivation. It allows learners to reflect on their learning, define misunderstanding, and assess their rate of progress. Students devote their efforts towards any material or abilities they think will be assessed.

Jensen (2012) states that assessment is defined as an integral aspect of the pedagogical process of designing lessons, implementing, and evaluating their success. By assessing the students, teachers not only can get feedback from students about the way they teach, whether their teaching is effective or not but also can find out whether they successfully achieve both the purposes and the objectives which they set for lessons or not.

Assessment for learning is presented at all stages of the learning process. Assessment for learning is generally known as a formative assessment or formative test. According to Brookhart (2019), formative assessment or formative test is a process by which assessment information is not only used by teachers but also students. Assessment encourages students to participate actively in the learning process. It also helps students become both self-regulated and confident learners. Bullock (2012) states that teachers use the assessment information to adjust their strategies of teaching. Students use the assessment information to adjust their strategies to learning. Teachers can both motivate and encourage students to learn by emphasizing progress and achievement rather than the failure of the students which is obtained from the assessment information.

In order to improve the dissemination, efficiency, and quality of education, Barbosa (2005) states that many educational institutions nowadays have been collaborating information and communication technologies in the teaching and learning process, including the assessment process. There are various online assessment tools that teachers can use in English teaching and learning. They are Kahoot, Quipper, and Quizizz. According to Bury (2017), Quizizz is considered as the most suitable online assessment tool in English teaching and learning.

Quizizz is an online assessment tool that can be downloaded and used free. This application can be used as formative assessment tools that can be created based on the curriculum. Rahayu (2018) states that Quizizz is a great online assessment tool that can help students to not only check their knowledge but also their progress in learning English. Rahayu (2018) also states that by using Quizizz, teachers not only can give tests but also can assign homework to the students as additional practice. The order of the question is put randomly for each student in the classroom. The type of the question in Quizizz is multiple choices which have at least two possible answers, and four as the most possible answer.

A previous study which is related to this study conducted by Bury (2017). The study is about, "testing goes mobile - web 2.0 formative assessment tools." The purpose of Bury's study is not only to assess but also to investigate the pedagogical impact of Kahoot! and Quizizz which are known as Web 2.0 assessment tools. Bury compares the students' responses to the use of non-gamified formative tests and the use of web-based assessment tools namely Kahoot! and Quizizz.

There are many advantages of using Quizizz in English teaching and learning. The use of Quizizz can add motivation to classroom activities as well as spark students' interest in the material being taught. The result of the previous study done by Bury (2017) shows that the use of online assessment tools like Quizizz motivates students and sparks the interest of the students in the material being taught.

Reid (2016) states that Quizizz organizes the data of the game well. The way Quizizz organizes and stores the data of the game is user friendly. It has a few options not only for students but also for the whole class. The data or reports can be checked through Quizizz website then it can be downloaded as an Excell spreadsheet which can be shared directly to the email of the students' parents. 
The researcher investigated Dynamic English Course students' perspectives toward the use of Quizizz as an online assessment tool for English teaching and learning because Dynamic English Course has given the formative test via Quizizz to the students since June 2019. This paper aimed to investigate Dynamic English Course students' perspectives toward the use of Quizizz as an online assessment tool for English teaching and learning, especially on a formative one. This study was expected to give other researchers and teacher contributions to encourage them in using Quizizz as an online assessment for their class.

\section{RESEARCH METHOD}

This study was a qualitative survey research. The subjects of the study were 20 students of Dynamic English Course. The data was collected by asking the students to fill the questionnaire. The data analysis was implementing the Likert Scale.

\section{Research Design}

In January 2020, the researcher tried to investigate Dynamic English Course students' perspectives toward the use of Quizizz as an online assessment tool for English teaching and learning, especially on a formative one, therefore the qualitative survey research method was used. The researcher used this method because it helped the researcher to describe the data obtained from this research.

\section{Subject}

The subjects in this study were 20 students of Dynamic English Course. In this research, the subjects were taken from a purposive sampling method. This method was chosen because the researcher would like to investigate the perceptions of both categories of students, the students with the above-average score, and the students with the below-average score.

\section{Instruments}

The researchers collected the data of the students' perceptions of the use of Quizizz as an online assessment tool for English teaching and learning from a questionnaire. The definition of questionnaire according to Dornyei (2007) was a number of questions to find out information about personal statements. The questionnaire used in this study consists of ten questions to find out the students' perception of the use of Quizizz as an online assessment tool for English teaching and learning, especially on a formative one.

\section{Data Analysis}

Data were analyzed by implementing the Likert scale. It was used to obtain data about students' perceptions of the use of Quizizz as an online assessment tool for English teaching and learning, especially on a formative one.

The researcher used Likert Scale requiring the students' perceptions in the form of five statements; Strongly Agree (SA), Agree (A), Neutral (N), Disagree (D), and Strongly Disagree (SD).

The researchers carried out the following procedures in analyzing data from the Likert Scale before describing it in narrative form. At first, the researcher scored each item in the scale; $5(\mathrm{SA}), 4(\mathrm{~A}), 3(\mathrm{~N}), 2(\mathrm{D})$, and 1 (SD). Next, the researcher calculated the score range for each set of questionnaire as follows; maximum score $=20 \times 5=100 \times 10=1000$, minimum score $=20 \times 1=20 \times 10=200$ and score range $(R)=1000-200=800$. Then, the researcher determined the criteria of score interpretation of each questionnaire set. The total score interpretation can be seen on the Table 1. 
Table 1

Total Score Interpretation

\begin{tabular}{cl} 
Score & Interpretation \\
\hline $1000-801$ & Strongly agree \\
\hline $800-601$ & Agree \\
\hline $600-401$ & Neutral \\
\hline $400-201$ & Agree \\
\hline 200 & Strongly disagree
\end{tabular}

Finally, the researcher described the data in narrative form. The data were also presented on a table and a bar chart.

\section{RESEARCH FINDINGS AND DISCUSSION Research Findings}

Based on the questionnaire result, it showed that the students' perceptions of the use of Quizizz as an online assessment tool for English teaching and learning were positive. Most of the students chose strongly agree, and none answered strongly disagree. The detail of the result can be seen from Table 2. It shows the students' perceptions of the use of Quizizz as an online assessment tool for English teaching and learning, especially on a formative one.

Table 2

Students' perceptions of the use of Quizizz as an online assessment tool for Englishteaching and learning

\begin{tabular}{clccccccc} 
No & \multicolumn{1}{c}{ Item } & SD & D & N & A & SA & HS & I \\
\hline 1 & Quizizz is interesting and fun & - & - & - & 1 & 19 & 950 & SA \\
\hline 2 & $\begin{array}{l}\text { Quizizz has an attractive } \\
\text { display }\end{array}$ & - & - & - & 5 & 15 & 750 & SA \\
\hline 3 & $\begin{array}{l}\text { Quizizz has many } \\
\text { challenging features }\end{array}$ & - & - & 5 & 5 & 10 & 500 & $\mathrm{~N}$ \\
\hline 4 & $\begin{array}{l}\text { I enjoy doing the test using } \\
\text { Quizizz }\end{array}$ & - & - & 1 & 16 & 3 & 640 & $\mathrm{~A}$ \\
\hline 5 & Quizizz feels like a game & - & - & 4 & 13 & 3 & 520 & $\mathrm{~N}$ \\
\hline 6 & $\begin{array}{l}\text { Quizizz doesn't make me } \\
\text { tense in doing the test }\end{array}$ & - & 2 & 3 & 9 & 6 & 360 & $\mathrm{D}$ \\
\hline 7 & $\begin{array}{l}\text { I can't cheat during the test } \\
\text { using Quizizz }\end{array}$ & - & - & - & 2 & 18 & 900 & $\mathrm{SA}$ \\
\hline 8 & $\begin{array}{l}\text { Quizizz creates a competitive } \\
\text { atmosphere }\end{array}$ & - & - & - & - & 20 & 1000 & $\mathrm{SA}$ \\
\hline 9 & $\begin{array}{l}\text { I feel encouraged to be } \\
\text { number one on the } \\
\text { leaderboard }\end{array}$ & - & 2 & 5 & 6 & 7 & 350 & $\mathrm{D}$ \\
\hline 10 & $\begin{array}{l}\text { Quizizz is better than the } \\
\text { traditional test }\end{array}$ & - & - & - & 3 & 17 & 850 & $\mathrm{SA}$ \\
\hline & Score (S) & 0 & 4 & 30 & 60 & 119 & & \\
\hline & S X Option Value & 0 & 8 & 90 & 240 & 595 & & \\
\hline & Total Score & & & $\mathbf{9 3 3}$ & & SA \\
\hline
\end{tabular}

Note: HS = Highest Score; I = Interpretation

From table 2, it can be seen that five of ten statements in the questionnaire were strongly agreed by most of the students. The five statements are Quizizz is interesting and fun, Quizizz has an attractive display, I can cheat during the test using Quizizz, Quizizz creates a competitive atmosphere, and Quizizz is better than the traditional test.

Meanwhile, the other five statements were responded with agree, neutral, and disagree. Most students agreed that they enjoy doing the test using Quizizz. The statements which were responded with neutral by most of the students were Quizizz feels like a game, and Quizizz has many challenging features. Most of the students disagreed with two statements from the 
questionnaire, they were Quizizz doesn't make me tense in doing the test, and I feel encouraged to be number one on the leaderboard.

The total score of the questionnaire result was 933 which was interpreted as strongly agree. The total score was obtained by multiplying the score with the option value, then sum it up.

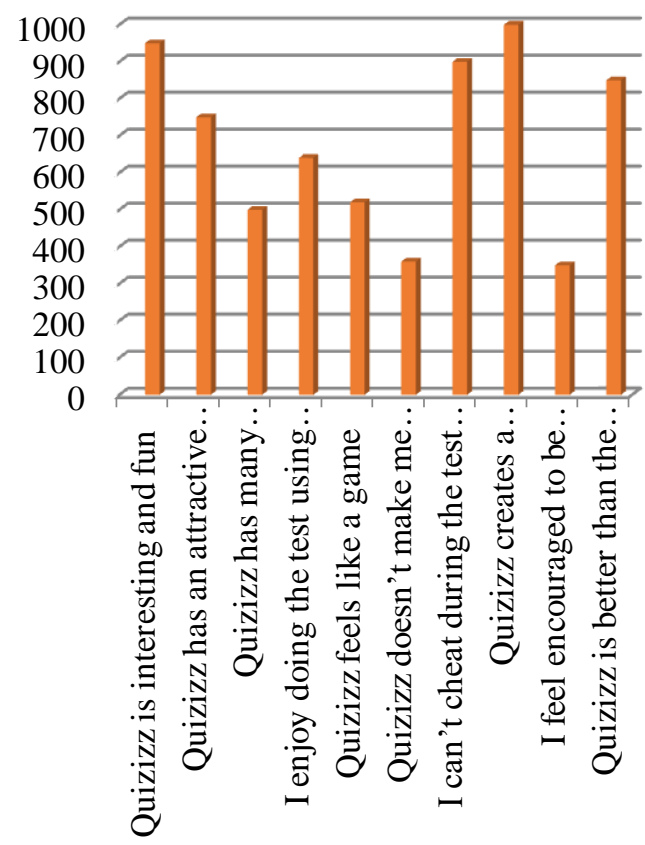

Figure 1. The highest score of each statement in the questionnaire.

The highest score is obtained by multiplying the highest number of the students' responses with the option value. Then, it is multiplied with ten. For example, the first statement in the questionnaire, Quizizz is interesting and fun, was strongly agreed by nineteen students and agreed by one students. To know the highest score of the first statement in the questionnaire is as followed $19 \times 5=95 ; 95 \times 10=950$. This score, 950 , is interpreted as strongly agree according to the calculation of Likert Scale.

From the highest score, it can be interpreted that four statements were strongly agreed by the students. The statements were Quizizz creates a competitive atmosphere, I can't cheat during the test using Quizizz, Quizizz is better than a traditional test, and Quizizz has an attractive display. There was one statement which agreed by the students. The statement was I enjoy doing the test using Quizizz. Two statements were responded as neutral by most students. The first statement was Quizizz feels like a game. The second statement was Quizizz has some challenging features. Meanwhile, most students disagreed with two statements in the questionnaire. The first statement was Quizizz does not make me tense in doing the test. The second statement which was disagreed by most students was I feel encouraged to be number one on the leaderboard.

\section{Discussion}

The Dynamic English Course students showed positive perspectives toward the use of Quizizz as an online assessment tool for English teaching and learning, especially on a formative one. It can be seen from the total score of the questionnaire result. The total score was 933 which was interpreted as strongly agree. This was the same as the previous study conducted by Basuki (2019) that the students believe that the students made a positive perception of the effectiveness of online quizzes towards language skills and components. 
A statement of the questionnaire which strongly agreed by all of the students was Quizizz creates a competitive atmosphere. This was in line with the previous study conducted by Bury (2017) that $79 \%$ of students agreed that it was fun to compete against other classmates using Quizizz. Basuki (2019) states that most students like the competitiveness in Quizizz session. By doing a test through Quizizz, students can see the result of their answers directly on the LCD projector. It may lead the students to be more competitive.

Most students were strongly agreed with three statements of the questionnaire. The first statement was I can't cheat during the test using Quizizz. This statement was strongly agreed by eighteen students while the two other students agreed. Basuki (2019) states that students have no chance to cheat each other since the questions and answers are shuffled for each student, they keep focusing on doing their work. This was in line with the statement of Barbosa (2005) that online assessment is applied is to minimize the academic dishonesty.

The second statement which was strongly agreed by most students was Quizizz is better than the traditional test. Seventeen students strongly agreed with this statement and three students agreed with it. None of them disagreed nor strongly disagreed with the statement. This was in line with a previous study conducted by Bury (2017) that $79 \%$ of students wished that the Quizizz testing was used more frequently. Bury (2017) also states that online tools like Quizizz was considered as a better test than the traditional test because it provides students with interactive learning environments that appeal to various learning styles.

The third statement which was strongly agreed was Quizizz has an attractive display. Quizizz's display is colorful and interesting therefore fifteen students strongly agreed that Quizizz has an attractive display while five students agreed with it. This was in line with a previous study conducted by Basuki (2019) which shows that most students agreed that Quizizz is exciting, interesting, motivating \& fun.

There was one statement which agreed by the students. The statement was I enjoy doing the test using Quizizz. Sixteen students agreed with this statement, three students strongly agreed and one student responded neutrally to this statement. None of the students disagreed nor strongly disagreed with the statement, it showed that the students enjoyed doing the test using Quizizz. Basuki (2019) states that Quizizz makes students enjoy the test and eager to grasp the lessons.

Two statements were responded as neutral by most students. The first statement was Quizizz feels like a game. This statement was agreed by thirteen students, strongly agreed by three students, and responded as neutral by four students. Although most students strongly agreed that Quizizz is interesting and fun, they did not consider that Quizizz feels like a game. The second statement was Quizizz has some challenging features. The highest score of this statement is 500 which is classified as neutral. A previous study conducted by Basuki (2019) shows that most students also respond neutrally to the statement of Quizizz has some special challenging features.

Meanwhile, most students disagreed with two statements in the questionnaire. The first statement was Quizizz does not make me tense in doing the test. The highest score of this statement was 360 which is classified as disagree. Although most students agreed that they enjoy doing the test using Quizizz, it does not mean that they do not feel tense in doing the test. This was different from the study conducted by Basuki (2019) that most students felt positive when playing Quizizz.

The second statement which was disagreed by most students was I feel encouraged to be number one on the leaderboard. Most students strongly agreed that Quizizz creates a competitive atmosphere but it does not mean that most of them want to be number one on the leaderboard. It can be seen from the highest score of the statement. The highest score of the statement was 350 which is classified as disagree. This was different from the study conducted by Basuki (2019) that most students tend to be number one on the leaderboard. 


\section{CONCLUSION}

In conclusion, the result of the study showed positive perspectives of the Dynamic English Course students toward the use of Quizizz as an online assessment tool for English teaching and learning, especially on a formative one.

The students strongly agreed that Quizizz has an attractive display which is interesting and fun, students can't cheat during the test, Quizizz creates a competitive atmosphere in the classroom, and Quizizz is better than the traditional formative test.

Furthermore, this study is expected to give other researchers and teacher contributions to encourage them in using Quizizz as an online assessment tool for their class.

\section{ACKNOWLEDGMENT}

I would like to express my deep gratitude to Mrs. Bekti Wirawati, who was my research supervisor, for her patient guidance, enthusiastic encouragement, and useful critiques of this research work. Her willingness to give her time so generously has been very much appreciated.

\section{REFERENCES}

BAL, S. (2018). Using Quizizz.com to Enhance Pre-Intermediate Students' Vocabulary Knowledge. International Journal of Language Academy. Vol. 6. 295-303. http://dx.doi.org/10.18033/ijla.3953.

Barbosa, H., \& Garcia, F. (2005). Importance of Online Assessment in the E-learning Process. ITHET 6th Annual International Conference. DOI: 10.1109/ITHET.2005.1560287.

Basuki, Y., \& Hidayati, Y. N. (2019). Kahoot! or Quizizz: the Students' Perspectives. English Language and Literature International Conference. DOI: 10.4108/eai.27-42019.228533.

Bury, B. (2017). Testing Goes Mobile - Web 2.0 Formative Assessment Tools. International Conference ICT for Language Learning. Retrieved February 12, 2019, from https://conference.pixel-online.net/ICT4LL/files/ict411/ed0010/FP/4060-ETL2655-FPICT4LL10.pdf.

Chaiyo, Y., \& Nokham, R. (2017). The Effect of Kahoot, Quizizz and Google Forms on the Student's Perception in the Classrooms Response System. International Conference on Digital Arts, Media and Technology (ICDAMT), 178-182. https://doi.org/10.1109/ICDAMT.2017.7904957.

Rahayu, I. S. D., \& Purnawan, P. (2018). The Use of Quizizz in Improving Students' Grammar Understanding Through Self Assessment. Advance in Social Science Education and Humanities Research. Vol 254. Retrieved March 5, 2019, from https://www.researchgate.net/publication/334422905_The_Use_of_Quizizz_in_Improv ing Students' Grammar Understanding through Self-Assessment.

Sukawatie, L. (2018). Using Quipper School Website as an Online Assessment for English Teaching and Learning. The 2nd English Language and Literature International Conference. Vol 2. Retrieved March 5, 2019, from https://jurnal.unimus.ac.id/index.php/ELLIC/article/download/3453/3362.

Suo, Y. M., \& Suo Y. J., \& Zalika, A. (2018). Implementing Quizizz as game based learning in the Arabic classroom. European Journal of Social Science Education and Research, 12(1), 208-212. https://doi.org/10.26417/ejser.v12i1.p208-212.

Viray, J. (2016). Quipper School and Its Effectiveness in the Academic Performance of Grade 8 Students in English. Research Gate. Retrieved March 10, 2019, from https://www.researchgate.net/publication/317032467. 
Zhao, F. (2019). Using Quizizz to Integrate Fun Multiplayer Activity in the Accounting Classroom. International Journal of Higher Education. Vol 8. https://doi.org/10.5430/ijhe.v8n1p37. 